\title{
How moves towards universal health coverage could encourage poor quality drugs: an essay by Elizabeth Pisani
}

\author{
(C) $(\Theta \otimes$ OPEN ACCESS \\ Universal health coverage depends on affordable medicines. But pushing down prices without also \\ investing in quality assurance will increase the sale of substandard and falsified drugs, warns \\ Elizabeth Pisani
}

\author{
Elizabeth Pisani associate professor, epidemiology \\ Erasmus School of Health Policy and Management, Rotterdam, The Netherlands, and King's College London, UK
}

Many governments in middle income countries are working hard to deliver on political promises that all their citizens will have access to quality health services, without being impoverished. They are finding that universal health coverage (UHC) doesn't come cheap.

Indonesia's national health insurance scheme, for example, has given out 223.4 million health cards since its inception in 2014. Nationwide, $73 \%$ of households said at least one household member had some health insurance in 2018 , up from $52 \%$ in 2013. ${ }^{12}$ Yet the scheme has been in permanent deficit; by 2018 it had a shortfall of 23 trillion rupiah ( $£ 1.3 \mathrm{bn}$; $€ 1.5 \mathrm{bn} ; \$ 1.6 \mathrm{bn}$. $^{3}$

Such deficits lead to belt tightening. Globally, about a quarter of all health spending is on drugs. In poorer countries the proportion is higher, and patients typically foot more of the bill. As governments move towards UHC, they increasingly pay for drugs that used to be paid for by patients-and look for ways to push prices down.

Cheaper drugs should mean more people effectively treated for the same budget, taking countries towards UHC. There's plenty of room for belt tightening. Generic and branded drug makers often charge whatever they can. ${ }^{5}$ Inefficient procurement and plain old corruption push prices up; some poorer countries pay 30 times more than the international reference price for basic generic drugs. ${ }^{6}$

But countries with under-resourced health budgets seeking to push down prices should be careful what they wish for. Recent research in China, Indonesia, Romania, and Turkey found evidence that drug manufacturers and distributors react quickly to keep profits as high as possible, ${ }^{7}$ potentially leaving patients exposed to substandard drugs, and creating opportunities for criminals to sell fake drugs.

\section{The downside of cheap drugs}

One way to maintain profits is to cut production costs-for example, by shifting manufacturing to cheaper locations or increasing worker productivity. Some manufacturers also mentioned more worrying measures, such as switching to cheaper ingredients or packaging, or skipping some quality assurance steps.

The result can be drugs that are so sloppily made that they don't dissolve properly in the body; that degrade before the patient takes them, sometimes because of cheap but inappropriate packaging or handling; or that are dangerously lacking in active ingredients. Similar problems have been reported from India, one of the biggest producers of cheap drugs. ${ }^{8}$

Drug regulators are supposed to spot this kind of corner cutting before procurement agencies buy them-and they do, but only if they have the right people, money, technology, skills, and incentives. Our study found that Turkey's drug regulator, which employs over 3000 well trained inspectors, is widely considered to provide effective oversight. ${ }^{7}$

But in the mad dash to reach UHC on a shoestring, many middle income countries underinvest in developing regulatory capacity.

Other forces are at play, too. Domestic drug makers are sometimes protected by local authorities, who have made promises to voters about jobs. Regulators in China and Indonesia told us that politicians, unwilling to sacrifice votes or tax income from industry, have discouraged thorough inspection of factories or warehouses. 
And there's no effective way to ensure that imported products are well made. The global drugs market operates on a "buyer beware" system-national medicines regulators don't have to assure the quality of products for export. Most imported drugs are waived through with paper based assurances; well resourced regulators only test a tiny fraction of imported drugs.

Around $30 \%$ of countries globally, according to the World Health Organization's latest count, don't have the capacity to regulate drugs properly, even at home. ${ }^{9}$ They take what they are sent, and it is not always first rate. A 2017 WHO summary of studies going back a decade estimated that one in 10 anti-infective drugs sold in low and middle income countries didn't meet minimum quality standards. ${ }^{10}$

\section{Filling the vacuum}

The most efficient producers probably can't cut production costs much further without compromising quality, and many aren't prepared to do that. But most are not prepared to disappoint shareholders by reducing profit margins either.

Procurement officials in the health ministry might decide that costs plus a $10 \%$ profit represents a "fair" price, but many drug producers and distributors of innovator and generic drugs calculate globally. They compare that margin with what they can make on other products or in other markets. If procurement practices drive prices down in one market, multinational companies just pull (or stay) out of the country. Domestic producers, who often have higher costs, sometimes stop making comparatively underpriced products entirely.

The Romanian government, struggling with large deficits in its national health insurance programme, in 2009 introduced a system designed to cut drug prices to the European minimum or below. After a radical revision of the price caps in 2015, prices fell by 16-25\% overnight, while European Union rules allowed drugs purchased in Romania to be resold in other countries. As a result, manufacturers withdrew about 2000 of 6200 authorised medicines from the Romanian market. Patients in Romania now look for those drugs on the internet, and doctors have reported using smuggled products.

Vacuums left by product withdrawal are easily filled by repackaged expired drugs or stolen or smuggled products that avoid taxes, import duties, or registration costs—and bypass regulatory oversight. The gap may also be filled by fakes, which cost almost nothing to make. WHO reports fakes in all classes of medicines, worldwide. ${ }^{11}$

High prices can also effectively create shortages for uninsured patients if they can't afford to buy a drug. In theory, UHC should reduce this risk, by covering the cost of more drugs. But even well resourced health systems restrict access to drugs people need or want. In England, for example, the NHS does not cover pre-exposure prophylaxis for HIV or the latest treatments for cystic fibrosis. In poorer countries, health insurance cards may facilitate access to health services but leave patients to pay for the most expensive prescriptions.

"Affordability shortages" help drug falsifiers in two ways. Firstly, falsifiers seek to maximise profits, and higher prices mean more profits for similar outlay and risk. Secondly, falsifiers are criminals, and patients who can't afford the prices at regulated outlets chase bargains on the internet, in street markets, or in buyers' clubs, which are harder to police.

\section{Selling the idea of quality}

Changes in health financing in efforts to achieve UHC in middle income countries may also eat into the revenues and profits of health providers serving insured patients. Less scrupulous providers may choose to top up their earnings by encouraging patients to buy drugs "off plan," often in the name of quality. This can increase patients' risk of getting falsified products.

An example comes from Indonesia, where in 2016 over 1000 children received fake vaccines, supposedly made by multinational producers GSK and Sanofi. Domestically produced, WHO prequalified vaccines were universally available free but earned doctors only a tiny fee. Paediatricians at some private hospitals preferred instead to offer imported vaccines at up to $\$ 40$ a shot, exploiting public tendency to consider high cost an indication of quality. To maximise earnings, some doctors bought the vaccines at cut price from roving salespeople. In fact, these fake vaccines were made in a garage in a Jakarta suburb. ${ }^{12}$

\section{What's the damage?}

Most fake drugs contain little or no active ingredient, and many contain toxic substances. These will obviously fail to cure and may harm. It's harder to assess the damage done by substandard drugs. Occasionally, drugs will be so badly made that they will poison and kill people, but that's mercifully rare. ${ }^{13}$ Generally, substandard drugs simply fail to prevent, treat, or cure disease as they should. Money is wasted, and patients are weakened and may die unnecessarily, though death is usually blamed on underlying illness and the role of poor quality drugs often goes unrecognised.

If the disease is infectious, prevention failure and longer illness can mean more transmission. Subtherapeutic doses of anti-infectives contributes to antimicrobial resistance, which can spread globally, thus reducing the effectiveness of quality assured drugs in well regulated markets. ${ }^{14}$

These concerns don't seem to ignite high profile, activist led campaigns. We know neither the prevalence nor the distribution of poor quality drugs. The logic of the market, and information from regulators, suggests that falsifiers more often target high value (often branded) drugs. Limited field surveys suggest substandard and degraded drugs are more often found among lower cost generics, especially where regulation is weak..$^{15}$

Generics are essential to every national health system, and most work just fine, even in less regulated markets. No one wants to risk undermining public confidence in the pharmaceutical bedrock on which UHC must be built. But unless quality assurance is strong enough, patients and doctors, who have no way of knowing what's actually in a pill or a vial, will continue to rely on sometimes unreliable signals of quality such as price and brand.

This creates a headache for governments striving to achieve UHC. Delivering better quality assurance requires investment in technology and skills, which countries need to build into budgets and practice. It's an inescapable part of achieving UHC.

\section{Access to drugs that work}

The market for quality assured drugs is disrupted by a mismatch between a largely socialised demand side, and an almost entirely capitalist supply side. In countries aiming for UHC, most decisions about buying drugs are made by governments aiming to minimise spending while protecting local jobs and revenues. These goals are often internally incompatible and certainly don't 
align with the aims of drug companies: to maximise global profits. Until that changes, substandard and falsified drugs will continue to flourish.

Existing efforts to change incentives for drug discovery, production, and procurement may improve access to affordable, quality assured drugs, but will take time. ${ }^{16}$ Three interim measures might help protect drug quality in the meantime.

Firstly, national discussions about fair prices should consider the globalised market. Recent efforts to promote open pricing could narrow the price difference between markets, especially if countries also share medicine registration and procurement mechanisms. But expect resistance from politicians or bureaucrats (claiming national sovereignty) who see in UHC an opportunity for kickbacks from national procurement contracts.

Secondly, increase regulatory resources in countries that export to low and middle income markets. This will also ruffle feathers, including among regulators in importing countries who worry about sovereignty and lost revenue. There are successful precedents, however. WHO's prequalification programme has increased quality assurance at source for drugs to treat HIV, tuberculosis, malaria, and reproductive health, for example. In the aviation industry, the 1944 Chicago Convention requires countries to accept flights from other nations only if their regulatory and safety procedures meet standards set by the International Civil Aviation Organisation. It also allows for cross national inspection, quality assurance, incident reporting, and investigation. ${ }^{17}$ There's no sign that national sovereignty has suffered as a result.

Thirdly, countries should adjust health budgets in response to other policy choices. For example, few nations can produce quality assured drugs as cheaply as the great exporting powerhouses, so if a country decides to promote local jobs by buying medicines from domestic producers, it will have to pay more. Similarly, stricter environmental rules for factories will push up production costs, and thus prices. If countries want to pursue such policies and deliver UHC, they'll have to increase budget allocations for drugs.

Taking account of the price of quality in policy and procurement decisions will not increase access to drugs, but it could help to ensure that the drugs that are on the market actually work as intended.

Elizabeth Pisani is an epidemiologist who researches the interaction between politics, human behaviour, and health. She currently focuses on the political and economic drivers of substandard and falsified medicines, with a particula interest in countries that are rapidly scaling up access to health services. This essay is informed by research in four countries, supported by the Wellcome Trust and Erasmus School of Health Policy and Management.
This article is part of a series commissioned by The BMJ based on an idea from the Harvard Global Health Institute. The BMJ retained full editorial control over external peer review, editing, and publication. Harvard Global Health Institute paid the open access fees.

Competing interests: I have read and understood BMJ policy on declaration of interests and have no relevant interests to declare.

Provenance and peer review: Commissioned; externally peer reviewed. This work draws heavily on the research and thinking of Adina-Loredana Nistor, Amalia Hasnida, Koray Parmaksiz, Jingying Xu, Maarten O Kok, and Pernette Bourdillon-Esteve. I thank Ibrahim Abubakar, Martin McKee, Gillian Buckley, and Paul Simpson for helpful comments on an earlier draft.

1 StatisticsIndonesia. Survei Sosial Ekonomi Nasional 2018. 2019.

2 Kesehatan BPJS. Jumlah Peserta program JKN. 2019. https://bpjs-kesehatan.go.id/bpjs/ jumlahPeserta.

3 Kesehatan BPJS. Laporan Pengelolaan program Tahun 2017 dan Laporan Keuangan Tahun 2017 (Auditan). 2018. https://bpjs-kesehatan.go.id/bpjs/index.php/arsip/categories/ Mzg/laporan-keuangan

4 Silverman R, Keller JM, Glassman A, Chalkidou K. Tackling the triple transition in global health procurement. Center for Global Development. 2019. www.cgdev.org/sites/default/ files/better-health-procurement-tackling-triple-transition.pdf.

5 Hill AM, Barber MJ, Gotham D. Estimated costs of production and potential prices for the WHO Essential Medicines List. BMJ Glob Health 2018;3:e000571. 10.1136/bmjgh-2017-000571 29564159

6 AfRx Consulting. Background research and landscaping analysis on global health commodity procurement. Center for Global Development, 2018. www.cgdev.org/sites/ default/files/CGD-procurement-background-afrx-research-landscape.pdf.

7 Pisani E, Nistor A-L, Hasnida A, Parmaksiz K, Xu J, Kok MO. Identifying market risk for substandard and falsified medicines: an analytic framework based on qualitative research in China, Indonesia, Turkey and Romania. Wellcome Open Res 2019;4:70. 10.12688/wellcomeopenres.15236.131131333

8 Eban K. Bottle of lies: the inside story of the generic drug boom. Ecco Press, 2019.

9 World Health Organization. Improving the quality of medical products for universal access. WHO Essential Medicines and Health Products. www.who.int/medicines/regulation/factfigures-qual-med/en.

10 World Health Organization. A study on the public health and socioeconomic impact of substandard and falsified medical products. 2017. http://who.int/medicines/regulation/ ssffc/publications/Layout-SEstudy-WEB.pdf.

11 World Health Organization. WHO Global Surveillance and Monitoring System for substandard and falsified medical products. 2017. www.who.int/medicines/regulation/ ssffc/publications/GSMS_Report.pdf.

12 Karmini N, Mason M. Vaccine scandal highlights Indonesian health system woes. Associated Press. 2016. https://apnews.com/b876f34ł36964122bcfe0408002d0415/ vaccine-scandal-highlights-indonesian-health-system-woes.

13 Lahore High Court. The pathology of negligence: report of the Judicial Inquiry Tribunal to determine the causes of deaths of patients of the Punjab Institute of Cardiology, Lahore in 2011-2012. 2012. http://apps.who.int/medicinedocs/en/m/abstract/Js22131en.

14 Pisani E. Antimicrobial resistance: what does medicine quality have to do with it? Antimicrobial Review, 2015. http://amr-review.org/sites/default/files/ ElizabethPisaniMedicinesQualitypaper.pdf.

15 Bate R, Jin GZ, Mathur A. Falsified or substandard? assessing price and non-price signals of drug quality. J Econ Manage Strategy 2015;24:687-71110.1111/jems.12114.

16 Wirtz VJ, Hogerzeil HV, Gray AL, etal . Essential medicines for universal health coverage. Lancet 2017;389:403-76. 10.1016/S0140-6736(16)31599-9 27832874

17 Havel BF, Sanchez GS. The international law regime for aviation safety and security. In: The principles and practice of international aviation law. Cambridge University Press, 2014.

Published by the BMJ Publishing Group Limited. For permission to use (where not already granted under a licence) please go to http://group.bmj.com/group/rights-licensing/ permissionsThis is an Open Access article distributed in accordance with the Creative Commons Attribution Non Commercial (CC BY-NC 4.0) license, which permits others to distribute, remix, adapt, build upon this work non-commercially, and license their derivative works on different terms, provided the original work is properly cited and the use is non-commercial. See: http://creativecommons.org/licenses/by-nc/4.0/. 